\title{
Role-player expectations regarding the education of nursing research
}

\author{
SCD Zeelie, D Tech, Technikon Pretoria \\ JE Bornman, D Phil, Technikon Pretoria \\ AC Botes, D Cur, Rand Afrikaans University
}

\section{Abstrak}

Die artikel doen verslag oor die verwagtings van rolspelers oor die onderrig van verpleegnavorsing. Die verwagtings van die rolspelers is belangrik vir twee redes:

eerstens as " $n$ faktor in die eksterne omgewing wat die formuleringsfase van standaarde beïnvloed en tweedens, as gevolg van die bewese probleme met verpleegnavorsing in nasionale en internasionale literatuur. Die rolspelerverwagtings is ondersoek deur middel van ' $n$ kwalitatiewe, eksplorerende en kontekstuele ontwerp. Die rolspeler populasie sluit die volgende groepe in: verpleegkundiges in bestuurs-, onderrig, kliniese en navorsingsposte, voorgraadse en nagraadse studente en die mediese professie. Naïewe sketse is gebruik om die data in te samel en kwalitatiewe data analise is gedoen deur gebruik te maak van Morse \& Field se data analise metode (1996:103-107) in kombinasie met Tesch soos verwys deur Creswell (1994:154-156). Sestig inisiele kategorieë is verfyn na ses finale kategorieë, naamlik die navorsingsonderrig program, personeel, studente, departementele beleid, befondsing en ondersteuningstelsels. Die rolspelerverwagtings is ondersoek as deel van ' $n$ navorsingstudie met die doel om 'n selfevalueringstelsel vir verpleegnavorsing daar te stel en as sulks is die rolspelerverwagtings van fundamentele belang in die ontwikkeling van standaarde vir die selfevalueringstelsel.

\section{Abstract}

This article reports on role player expectations regarding the education of nursing research. The importance of the role player expectations are two-fold: firstly as a factor in the external environment influencing and guiding the formulation phase of the development of standards and secondly, due to the clear indications of problems regarding nursing research in the nursing profession in literature. The role player expectations were elicited using a qualitative, exploratory and contextual design. The role player population included nurse educators, nurses in managerial, clinical and research positions, students and the medical profession. The data was gathered using the naïve sketches and qualitative data analysis was done using Morse \& Field's approach (1996:103-107) in combination with Tesch's data analysis approach as cited by Creswell (1994:154-156). Sixty initial categories were narrowed down to six final categories, which are the research learning programme, personnel, students, departmental policies, funding and support systems. The role player expectations were elicited as part of a research study aiming tot develop a self-evaluation system for quality assurance in nursing research and as such, the role player expectations plays a pivotal role in the development of standards for the self-evaluation system.

\section{Introduction}

Nursing research is an essential component in the art and science of nursing, yet, as indicated in national and international literature, several problems exist regarding nursing research. The product of the education of nursing research, the registered nurse, negates the responsibility of producing scientific nursing knowledge. Research is done in academic settings and as part of career advancement. When delving deeper into this problem, abundant literature is available that proves that a general negative attitude towards nursing research exists.
By eliciting the role-player expectations, specifically with the aim of formulating standards to improve the quality of the education of nursing research. these problems may be addressed. Standards based on role player expectations will increase ownership of the standards and ground the standards in reality. According to Muller (1998:608), eliciting the expectations of role players is part of the formulation phase of standards and it determines what workers and experts in a specific discipline consider as good practice. The aim of this article is to report on the research done to elicit the role player expectations regarding the education of nursing research. 


\section{Research Methods}

A qualitative, exploratory and contextual design has been used to elicit the role player expectations regarding the education of nursing research. The context encompasses institutions of higher education and hospitals in South Africa.

\section{Population}

The population for the study was registered nurses, specifically in clinical, educational, and managerial positions and registered nurses in research positions. Under- and postgraduate nursing students were also included. The medical profession in an academic environment, and the nursing professional organisation were also included in the population. Specific criteria for participation were drafted and the sample was chosen conveniently and purposively (Brink, 1996:140-1). Convenient in the sense of availability in South Africa through electronic means or the postal system and purposive due to the criteria set for inclusion in the sample. The criteria were as follows:

- Involved in teaching nursing research, in possession of a doctorate or masters degree or identified as a knowledgeable person in this regard by a person of the same institution or belonging to another specific role-player category

- Willingness to participate

- Availability

\section{Data gathering}

Due to the qualitative nature of the study, a self-report technique - naïve sketches were used to obtain the expectations regarding nursing research (Brink, 1996:153). A single central question was drafted and pilot tested. The question was formulated as follows:

For you personally, what are your expectations regarding the education of nursing research?

In Afrikaans the question was formulated as:

Vir $u$ persoonlik, wat is $u$ verwagtings aangaande die onderrig van verpleegnavorsing?

Naïve sketches were chosen as the data gathering instrument due to specific advantages it offers. The advantages in using naïve sketches as a data-gathering instrument are that the respondent can write down, in his/her own time, their expectations. The result is a written document ready for analysis with rich information regarding the subject. Due to the nature of the naïve sketches respondents can be contacted anywhere in South Africa.

Contact information was obtained from ninety (90) hospitals in all nine provinces of South Africa. The instructional letter and the naïve sketch form was posted, faxed, or emailed to the nursing managers of the hospitals. The managers $(n=21)$, who chose to respond, responded within two weeks. All institutions of higher education with a department of nursing in South Africa were approached with a request for naïve sketches. Nineteen responses were received. Clinical nurses $(n=5)$ in Tswane Metropolitan area (Pretoria) were asked for naïve sketches. The request was done personally. These positions include nurses working in hospital and primary health clinics. Students $(n=17)$ were approached in groups or individually. Researchers: educational, nursing and medical $(n=6)$ were asked personally and answered via fax, e-mail or handed the naïve sketch back personally. The total number of naive sketches received was sixty-nine (69).

\section{Data analysis}

The data collected were written statements - nonnumeric in nature, which requires content analysis. The data were analysed according to Morse and Field's (1996:103-107) approach. The authors name four cognitive processes integral in the analysis of qualitative data, namely comprehending, synthesising, theorising, and recontextualising. Tesch's data analysis approach as cited by Creswell (1994:154-156), was combined with Morse and Field's approach for the first two cognitive processes. These processes occur sequentially, because each process builds on the previous one. A protocol based on Morse and Field's approach combined with Tesch's data analysis approach has been drafted for the coder and the co-coder to serve as a basis for the coder when coding the raw data. The results reported in this article represent the data after the first two cognitive processes were completed.

\section{Independent coding}

The use of an independent coder is another essential component in qualitative data analysis to ensure trustworthiness of the data. Poggenpoel (1998:345) describes a procedure to follow regarding the independent coder. The person chosen must fulfil acceptable criteria such as experience in coding qualitative data and knowledge of the subject. The coding was open because the independent coder was not be given any categories or prearranged themes. After both the researcher and the coder completed coding, a meeting was arranged for consensus discussions on the topics and categories reached independently.

\section{Criteria for the independent coder}

The criteria set for the independent coder, of phase I of the study, is as follows:

- Knowledgeable regarding research, specifically qualitative research and coding of verbal data.

- Geographically available for consensus meetings.

- Completed doctoral studies.

- Participation in post-doctoral research activities.

- $\quad$ Published in peer reviewed journals.

A meeting was arranged with the independent coder for consensus discussions on the results of the data analysis. The following points emerged from the meeting:

- Saturation was achieved with the $29^{\text {th }}$ naïve sketch by the researcher and the $31^{\text {st }}$ naïve sketch by the independent coder. 
The meeting with the independent coder fulfilled the requirement of reflexivity (Lincoln \& Guba, 1985:290), in an effort to maintain rigor in the scientific inquiry and achieve trustworthiness of the data. In the computer spreadsheet, each category was numbered and the registration number of the naïve sketch from which the specific category originated or corresponding categories in following naive sketches, was listed. In this way, the sequence of the development of the categories can be traced as well as the specific naïve sketch from which the category originated. The reproducibility of the qualitative data analysis was seen as important in order to fulfil the three prerequisites for trustworthiness:

- $\quad$ Prove that the nominated role-player populations are present in the analysis.

- Auditability of the qualitative data analysis, as the categories can be traced back to the naïve sketches where it originated.

- Saturation of the data.

Due to the need to demonstrate saturation and to ensure referential adequacy, the pertinent information is provided in table 1.1.

\section{Table 1.1 Data saturation and achievement of referential adequacy}

\begin{tabular}{|l|l|l|}
\hline Number of naïve sketches obtained & & 69 \\
\hline Number analysed with new categories emerging & 29 & \\
\hline Additional number analysed with no new category & 9 & \\
\hline Number not analysed & 31 & \\
\hline Total & 69 & 69 \\
\hline
\end{tabular}

Data saturation and referential adequacy was thus attained, partially fulfilling the requirement of trustworthiness (Lincoln \& Guba, 1985:290), as well as adhering to the recommendations for auditability by Burns and Grove (1997:528). Trustworthiness is discussed in the next section.

\section{Trustworthiness}

The data generated via the naïve sketches are qualitative in nature and as such, the data should be assessed for trustworthiness. According to the authors, the basic issue in relation to trustworthiness is to be able to persuade the audience that the findings are worth paying attention to, and worth accepting (Lincoln \& Guba, 1985:290). The implementation of the trustworthiness criteria of Lincoln and Guba in Phase 1 of the research study is set out in table 1.2.

According to the criteria set by Lincoln and Guba (1985:290), the data is trustworthy and thus the results are discussed in the following section.

\section{Ethical considerations}

Participation was voluntary as a letter inviting participants to participate and explaining the scope of their participation was attached to the naïve sketch form. Anonymity and confidentiality was ensured as no name was written on the form. A space was earmarked on the form where the respondent could indicate the role player population group he or she belonged to.

\section{Results}

The number of categories after the first cognitive process came to sixty (60) initial categories. In the second process, synthesizing, the initial categories are narrowed down to final categories to enable the researcher to synthesise the data in preparation for the third process namely theorising. The first two cognitive processes of Morse \& Field's approach (1996:103-107) represent the expectations of the role players regarding the education of nursing research. The final categories realised as research learning programme, personnel, students, departmental policies, funding and support systems. The results of the study are discussed in terms of the final categories. The quotes from respondents originally written in Afrikaans were translated in English and written directly below the Afrikaans quote in italics. Following is a narrative description of the categories:

\section{i) Nursing research learning programme}

Several expectations emerged regarding the learning programme and the expectations are discussed under the following headings: content, didactic concept, assessment, philosophy and outcome.

\section{a) Content}

Several expectations regarding the content of the research learning programme were uncovered. Aspects named are that standards should exist for research design and terminology and also that the student's scientific writing ability should be actively developed.

"Skryf as "n navorsingsvaardigheid moet ontwikkel word." "Writing as a research skill should be developed."

The importance of nursing research in the total programme was also described.

"Dat verpleegnavorsing ' $\mathrm{n}$ belangriker komponent in verpleegopleiding en in die verpleegpraktyk sal inneem." "Nursing research should comprise a more significant component in nursing education and the nursing practice."

"Daar moet gewaak word daarteen om navorsing as vak net in ' $n$ kurrikulum te druk sodat die keuringsrade van opleidingsinstansies tevrede is, maar daar te min tyd is in 
Table 1.2: An exposition of the implementation of Lincoln and Guba's (1985:290) trustworthiness criteria.

\begin{tabular}{|c|c|}
\hline & Methods to ensure trustworthiness \\
\hline $\begin{array}{l}\text { Prolonged and varied engagement in } \\
\text { the field }\end{array}$ & $\begin{array}{l}\text { Sixty-nine naive sketches were obtained with the role-player populations } \\
\text { represented by professional nurses - educators, managers and clinical } \\
\text { registered nurses, student nurses, researchers, the medical profession, } \\
\text { and the professional organisation. }\end{array}$ \\
\hline Reflexivity & $\begin{array}{l}\text { Planned use of an independent coder fulfilling specific criteria using a } \\
\text { specific coding protocol. - Consensus discussions with independent } \\
\text { coder. }\end{array}$ \\
\hline $\begin{array}{l}\text { Triangulation } \\
\text { Data sources }\end{array}$ & $\begin{array}{l}\text { Triangulation of data sources } \\
\text { Data gathered with one central question from multiple participants of } \\
\text { various sub groups including professional nurses, student nurses, the } \\
\text { medical profession, regulatory authority. } \\
\text { - Naïve sketches ( } n=69 \text { ) used as data gathering methods using the same } \\
\text { central question. }\end{array}$ \\
\hline $\begin{array}{l}\text { Referential adequacy } \\
\text { Source data }\end{array}$ & $\begin{array}{l}\text { - All categories are represented and enough data have been gathered to } \\
\text { ensure saturation. } \\
\text { Referential adequacy was ensured by having } 31 \text { naïve sketches not ana- } \\
\text { lysed, as saturation has been achieved after } 38 \text { of } 69 \text { naïve sketches were } \\
\text { analysed }\end{array}$ \\
\hline Structural coherence & $\begin{array}{l}\text { - The focus of the study remained on one central question regarding the } \\
\text { expectations regarding nursing research }\end{array}$ \\
\hline Thick description & $\begin{array}{l}\text { - The protocol and design of this research study provides a clear descrip- } \\
\text { tion of the methods, and the scientific report describes the results } \\
\text { obtained. } \\
\text { Detailed summary of the context. } \\
\text { - Number and nature of respondents. } \\
\text { - Detailed reports of the results of the study. }\end{array}$ \\
\hline Transferability to a similar context & $\begin{array}{l}\text { Purposive sampling of professional nurses: managerial, educator and clini- } \\
\text { cal, student nurses, members of the medical profession, and regulatory } \\
\text { authority }\end{array}$ \\
\hline Dependability audit & $\begin{array}{l}\text { - The raw data of the naïve sketches was co-coded, audited and archived } \\
\text { to permit checking of the findings against the raw data. } \\
\text { Protocol developed and implemented for management of naïve sketches } \\
\text { on receipt. } \\
\text { Data analysis protocol developed and implemented for the naïve sketches } \\
\text { based on Field and Morse's approach in combination with Tesch's ap- } \\
\text { proach. } \\
\text { - Use of an independent coder, chosen according to specific criteria. } \\
\text { Documented data and decisions as the analysis progressed as evidence } \\
\text { of the way the conclusions were reached. } \\
\text { An audit trial was created to ensure that the results obtained from the raw } \\
\text { data were auditable. }\end{array}$ \\
\hline
\end{tabular}


die kursus om navorsing werklik te geniet."

"It should be guarded against adding research in the curriculum to satisfy regulatory requirements, but not allow enough time to really enjoy research."

\section{b) Didactic concept}

Expectations regarding the didactic concept include aspects such as practica hours as part of the research course where students can obtain practical experience and one example of how such experience can be obtained is apprenticeships. Another expectation in this regard is that nursing students should be involved in research studies in the hospital as field workers or co-workers. Group work is also suggested. Lectures, which are clear and understandable, are also expected.

"Die dosent moet instaat wees om die inligting oor te dra op die vlak wat die student is en nie op die vlak van haar eie kennis nie. Ek het nou al 2 maal voorheen navorsing as deel van my studies gedoen en het nog steeds nie'n idée hoe om dit reg te doen nie omdat kundiges ingekry is om die inligting bymekaar te sit en te verwerk aangesien ons niks van die onderwerp geweet het nie."

"The lecturer must be able to transfer knowledge on a level that is understandable to the student and not on her own level of knowledge. I have done a research course twice before, but still have no idea how to do research as experts were employed to do the data analysis, because we did not understand research at all."

The expectation is that teaching should be an enjoyable experience, and that a positive atmosphere should be created which is non-threatening and fun.

"Dat die onderrig sal voldoen aan die belofte wat aanvanklik gemaak is aan die begin van die jaar. Dat navorsing 'lekker' sal wees - jy sal dit geniet."

"The education should fulfil the initial promise made at the start of the academic year. That research would be fun and enjoyable."

"Teaching of the research process is an art - it needs to be non-threatening, challenging and fun."

\section{c) Curriculum}

Regarding the curriculum, one of the most prominent expectations is that research should commence in the first year of the basic nursing course. This requirement is seen as an essential element in the creation and maintenance of a research culture in a nursing department.

"All nursing education departments should strive towards or maintain a research culture. Such as culture can only be achieved if ... students are introduced to research principles, processes and activities from the first year."

"Nursing education needs to develop nursing research from day one."

The aim is to engender a respect for evidence-based nurs- ing and change the paradigm of best practice, based on the historical evolution of nursing care. Standards should exist for nursing curricula, which should be similar between various institutions of higher education. The expectation also exists that research education should be a separate course or module. Statistics should be taught at a basic but understandable level. Certificate courses, workshops and presentations should be available for those wishing to upgrade their knowledge and skills. From the students' point of view, there should be enough time in a course to do research:

"Daar moet genoeg tyd wees om navorsing the doen, jy kan dit nie afjaag nie!"

"Enough time should be allowed to do research, it cannot be rushed!"

"Genoeg tyd en klas tyd is essensieel. Navorsing is nie iets wat jy binne 'n dag of twee kan doen nie. “

"Enough time is essential. Research is not something that can be done in a day or two."

Regarding the process of the learning programme, the following expectations are pertinent. The research process should be the basis of all research. Nursing research theory should be correlated with practica in research and be made user-friendly, especially for clinical nurses without much expertise.

"Registered nurses should be taught the theory component in small modules, followed immediately by on-the-job application to ensure theory-practice integration. Currently the teaching of nursing research at university level is intimidating to the non-academic registered nurse and must therefore be made user-friendly and very relevant to her area of clinical expertise."

"Dit is baie moeilik om eers alle teorie te leer en dan nie toe te pas nie"

"It is very difficult to study all the theory of research and then not being able to apply the theory."

"Al die jare al word ons gedwing om inligting uit jou kop te leer, sonder dat jy dit regtig begryp of kan toepas. Daar is geen sin daarin om teoretiese kennis te hê, maar dit nie kan toepas of regtig verstaan nie."

"All the years we have been forced to memorise facts without understanding or applying the knowledge. There is no sense in having the theoretical knowledge but not being able to apply the knowledge or really understanding research properly."

Interest in research should be stimulated and cultural issues must be taken into account during teaching research.

"Betrek studente by observasie navorsing. Laat studente self enige projek oor enige aspek in hospitale doen om te help met bewusmaking en resultate te kry, of probleme te identifiseer en daarop navorsing te doen."

"Involve students in observation research. Let students do a project on any aspect in a hospital to increase aware- 
ness and to get results, or to identify a researchable problem and do a study."

\section{d) Learning programme -assessment}

The following expectations were identified with regard to assessment. Research knowledge, skills and competencies should be a co-indicator of the successful completion of specialist nursing courses. Recognised criteria should exist regarding the size of documents for mini-dissertations, dissertations and theses. Another point is that standards should exist for the acceptability of theses and dissertations.

"Acceptability of the dissertation or theses must be based on the chosen criteria and not necessarily on the marks."

In terms of the process of assessment, an expectation is that evaluation should assess understanding as well as practical ability in research.

"Geen teoretiese toetse nie. Van geen waarde byvoorbeeld die verskillende stappe. Daar sal altyd genoeg literatuur beskikbaar wees om dit op te lees. Begrip en toepassing is van belang."

"No theoretical tests - it is of no value. For example the various steps - there will always be enough literature available to read. Understanding and application is of importance."

\section{e) Learning programme philosophy}

Research should be done within the unique ethics base and constraints of nursing.

"Nursing research must comply with all the criteria pertaining to the ethical code for human ... research."

\section{f) Learning programme outcome}

Several expectations regarding the outcome of the nursing research learning programme were obtained. These entail that all research should culminate in published articles and that research done should be functional. The ultimate goal of research is to solve the problems experienced in practice, to gain evidence of and for nursing practice and not just to gain an academic qualification. Another expectation is that research should be implemented in nursing practice and nursing education.

Understanding and insight should be enhanced in the student with the development of an enquiring mind as a major expectation, as well as the ability to critically appraise research articles.

"Research is not restricted to formal qualifications, but may be conducted at all levels of breadth and depth for the purpose of problem solving, describing phenomena, seeking evidence for and of professional practice and the development of more effective practices in a designated profession."

"Navorsing moet vanaf die basiese kwalifikasie deur die studente aangeleer word. Dit moet op so " $n$ wyse aan die leerder voorgehou word dat die leerder "n "enquiring mind" sal ontwikkel."

"Research should be taught from under-graduate level. Through teaching research, an enquiring mind should be developed in the student."

"Om by die leerder ' $n$ vra-houding te skep. M.a.w. dat daar " $n$ bewustheid gekweek word om dit wat elke dag rondom hul gebeur vraend te bekyk."

"To foster an enquiring attitude in the student. Thus cultivating an attitude that questions what happens in their surroundings every day.

Research related outcomes should be set for baccalaureate, masters and doctoral programmes. The outcomes of the previous level should be the entry level for the next level.

"Dit is belangrik dat navorsingsgerigte uitkomste vir die leerder gestel word... Die uitkomste kan dan as intreevlak vir nagraadse studente gestel word."

"It is important to set research related exit level outcomes for the student and that these outcomes serve as the entry levels for post graduate students."

An important expectation regarding the outcome of the learning programme is that students should feel competent to do and use research.

\section{ii) Personnel}

Expectations regarding personnel will be discussed as the competencies required, multidisciplinary research, productivity and leadership positions needed in nursing research.

\section{a) Personnel-competencies}

A number of expectations were elicited in terms of personnel competencies. Several respondents suggested that the creation of a rolling model in the department of nursing should increase the general level of expertise regarding research. A standard should exist regarding the qualifications of nurse educators (percentage with doctorates, masters, improving qualifications and doing postdoctoral research).

"Staffing criteria to include predetermined percentages, either de facto or laid down as a strategic objective: percentage academic staff with doctoral and masters degrees, percentages improving qualifications and those busy with nonforma research into identified issues and the percentage of staff busy with post doctoral research."

Research supervision was also discussed and specifically the need for experienced supervisors and criteria for the process of supervision. An expectation that was raised by many respondents is the characteristics and competencies of the nurse educator.

Some expectations in this regard are as follows: enthusiastic about research, a good communicator, patient, available, knowledgeable, should be a nurse, a role model and committed to students. 
“... die dosent moet nooit wys dat sy moedeloos voel omdat ek so sukkel om die begrippe te verstaan nie - dit is totaal vreemd en neem tyd om deel te word van jou denkwyse." "... the lecturer should never show that she is discouraged because I am struggling to understand the principles of research - it is totally foreign and takes time to be integrated into your way of thinking."

"Die dosent moet in staat wees om die inligting oor te dra op die vlak wat die student is en nie op die vlak van haar eie kennis nie ..."

"The lecturer must be able to transfer knowledge on the level of the student and not on her own level of knowledge ..."

"Die persoon wat die onderrig aanbied moet ' $n$ kenner wees ... en sy moet haarself al heelwat navorsing gedoen het." "The person doing the lecturing should be an expert... and she should have done quite some research herself."

"Die persoon moet goeie kommunikasie vaardighede aan die dag lê."

"The person should have good communications skills."

"Lecturers must be enthusiastic about their subject and be ongoing learners and demonstrate this to their students."

\section{b) Personnel - multidisciplinary research}

It is expected that nursing educators should partake in collaborative multidisciplinary research projects.

"As nursing research cannot be seen in isolation, collaborative research projects should be entered into a much greater degree. Research can no longer be conducted solely within the confines of academic institutions. Standards set should include this domain."

"Partnership and collaboration with other sectors to enhance diverse skills on research."

\section{c) Personnel - productivity}

Personnel should be actively engaged in doing research and publish in peer review journals.

"With regard to academic staff, I expect them to be engaged in at least one research project at any time."

"I also expect every research project to terminate in at least one peer reviewed publication. Quality of their research is therefore established not by examination, but by the level of funding it has drawn in, and the level of publication it leads to."

"'n Verwagting kan wees om aan een departemente projek deel te neem en om een eie projek per jaar te hê - Dit moet met "n publikasie opgevolg word."

"An expectation could be that a person should participate in one ongoing departmental research project and one personal project - which should lead to a publication."

\section{d) Personnel - leadership positions}

An expectation exist that nurse researchers should be in leadership positions in national projects, team projects and project leadership.

"Studente moet onderrig word om oor die rol van " $n$ professionele persoon binne ' $n$ navorsingspan en die rol van "n persoon as die leier van "n navorsingspan."

"The students should be taught regarding the role of $a$ professional person in a research team and the role of a person as the leader of the research team."

"Furthermore, I expect their research expertise to lead more national projects, team projects and to project leadership."

\section{iii) Students}

Expectations were raised in terms of research students, and these are discussed in terms of the position and support of the student in the department. Most important is that the student should have the necessary research capabilities after completing a research course.

Student's position as fledgling scientists should be recognised.

"ek wil voel dat dit NB is dat ek moet navorsing doen in die dosent se oë en dat verpleging mense soos ek nodig het om dit te doen."

"I feel that it is important that, in the eyes of the lecturer, I must do research and that nursing needs persons like me to do it."

\section{iv) Departmental policies}

Departmental policies, as an expectation of a standard in nursing research, are discussed under the expectations raised for various departmental policies to be developed and implemented.

Several expectations came to light with regard to departmental policies. These included:

- The creation of a forum as a marketplace for research results, debate and networking for all personnel and students.

- The creation and maintenance of a research culture in the department.

- Departments of nursing education/institutions of nursing science should develop broadly defined research programmes within which students can choose their own topics. These research programmes should reflect the expertise of the department.

- $\quad$ Policy should exist stating what is expected of personnel and the procedures they are to follow.

- Standards should exist concerning the nurse educator/student ratio.

- Research should address the priorities of health

- The department should fulfil a resource function for researchers doing post-doctoral research in their 
professional practice.

"Alhoewel studente toegelaat moet word om hul eie onderwerpe te kies, moet daar breed gedefinieerde navorsingsareas wees in die departement en studente moet aangemoedig word om binne die areas te werk. Die navorsingsareas moet die kundigheid in die departement weerspieël."

"Although students should be allowed to choose their own projects, there should be broadly defined research areas in the department and students should be encouraged to choose a project within the defined areas. The research areas should reflect the expertise in the department."

"Die departement moet ' $\mathrm{n}$ navorsingsbeleid hê wat sal uitspel wat van doseerpersoneel verwag word en prosedures wat gevolg moet word."

"The department must have a research policy that specifies what is expected from the lecturers and which procedures should be followed."

"'n Forum moet geskep word waar studente hul navorsing kan voordra en deelname kan hê aan die debat wat navorsing moet stimuleer."

"A forum should be created where students can present their research and participate in the debate which should stimulate research."

\section{v) Funding}

Funding for both students and departmental research projects are explicit expectations in nursing research. Two expectations regarding funding were raised; firstly that the department has a function in obtaining funding and also that funding should be available for students to facilitate their efforts to do research.

"... the more senior they become, the more I expect them to be able to access research funding, firstly from within the university, and in more senior positions, from outside."

"Finansiële hulp/sponsers wat navorsing vir studente moontlik kan maak."

\section{"Financial support to enable students to do research."}

\section{vi) Support systems}

Expectations are also broached regarding the nature and accessibility of the two main support systems namely the statistical department and the library. Support systems fulfil an important function in facilitating research in an institution of higher education. Expectations in this regard are as follows:

- The availability of a library and statistical support services.

- $\quad$ The library should be sufficiently equipped to sup ply in the needs of students up to doctoral level.

- Students should be taught how to use various resources, e.g. the library.
- Students should be oriented in the library and statistical support department early in the year.

- Students, who are not computer literate, should be assisted in literature searches.

"Verder, dat ondersteuningstrukture in plek moet wees om hulle te help om hierdie studies op te stel, te implementer en te interpreteer. "

"Further, support systems should be in place to enable students to initiate, implement and interpret studies."

"Meer hulp van die biblioteek om inligting te bekom indien die inligting nie onmiddelik beskikbaar is nie."

"More support from the library to obtain information that is not readily available."

"Meer opgeleide mense moet by die biblioteek wees om mens te help. Ek was by 3 verskillende mense waarvan net een my kon help. Hulle moet nuwe studente kan leiding gee - dis NB en voorkom baie moedeloosheid en frustrasie." "More trained persons in the library to assist a student. I approached three different people for assistance, but only one could help me. They should provide guidance to new students - it is very important and will prevent discour. agement and frustration."

\section{Conclusion}

These expectations regarding education of nursing research represent feelings, experiences and wishes in the role-player population within their own world-views and the context of their own training and current positions. These expectations identifies what are considered as good practice at grass roots level as well as specialists in the education of nursing research in institutions of higher education. Hence, the research provides a basis for the formulation of standards for quality assurance in nursing research.

\section{Recommendations for standards formulated from the research}

Standards should be formulated regarding the following:

- The research learning programme: the standard should include aspects such as content, didactic concept, assessment, philosophy and outcome.

- Personnel: important aspects to be incorporated in a standard are the competencies required, the promotion of multidisciplinary research, scholarly productivity and leadership positions in nursing research, both nationally and internationally.

- Students: standards should strengthen the position of the student as a fledgling scientist.

- Departmental policies: specific research related departmental policies are advocated.

- $\quad$ Funding: standards should include the department's responsibility to obtain funding for research and to assist students with funding for their research.

- Support systems: specific standards must be developed regarding the library and statistical support available for research. 
Once standards are developed, a self-evaluation system can be designed and implemented to improve the quality of research in departments of nursing.

\section{Bibliography}

BRINK, HI 1996: Fundamentals of research methodology for health care professionals. Kelwyn: Juta.

BURNS, N. \& GROVE, SK 1997: The practice of nursing research conduct: critique \& utilization. Philadelphia: WB Saunders.

CRESWELL, JW 1994: Research design: qualitative and quantitative approaches. Thousand Oakes: Sage.

LINCOLN, YS \& GUBA, EG 1985: Naturalistic Inquiry. Newbury Park: Sage.

MORSE, JM \& FIELD, PA 1996: Nursing research: the application of qualitative approaches, 2 nd ed. London: Chapman \& Hall.

MULLER, M 1998: Quality Improvement in Health Care. In. Booyens, S.W. (ed). 1998. Dimensions of Nursing Management. Kelwyn: Juta.

POGGENPOEL, M 1998: Data analysis in qualitative research. (In: De Vos, A.S. (ed). Research at grass roots: a primer for the caring professions. Pretoria: van Schaik.) 